\title{
Lack of papillomavirus (HPV) in pterygia of a Brazilian sample
}

\author{
Ausência de papiloma virus(HPV) em pterígios de uma amostra brasileira
}

\author{
Silvana Artioli Schellini ${ }^{1}$ \\ Erika Hoyama² \\ Claudia Akemi Shiratori ${ }^{3}$ \\ Regina Hitomi Sakamoto ${ }^{4}$ \\ João Manuel Grisi Candeias 5
}

\begin{tabular}{|l|}
\hline ABSTRACT \\
\hline Purpose: Because the influence of papillomavirus (HPV) in pterygium \\
pathogenesis is controversial, the aim of this study was to identify \\
whether it is present in the pterygia lesions in our region. Methods: \\
Thirty-six patients with unilateral primary pterygia were submitted to \\
excision of pterygia and a sample of normal conjunctiva. Tissues were \\
submitted to polymerase chain reaction (PCR) evaluation for papilloma- \\
virus DNA detection. Results: We were unable to detect any HPV DNA \\
in all studied specimens. Conclusion: According to our results papilloma- \\
rivus is not important for pterygium formation.
\end{tabular}

Keywords: Papillomavirus; Pterygium; Polymerase chain reaction, HPV DNA probes

\section{INTRODUCTION}

Pterygium is a common conjunctival disease in tropical and subtropical areas $^{(1)}$. Despite various studies, the pathogenesis of pterygium remains unclear. Exposure to sun, genetic predisposition and environmental factors are well established as part of its multifactorial pathogenesis ${ }^{(2)}$.

Other etiologic factors have been reported: molecular genetic changes such as heterozygosity loss, increased p53 expression and presence of oncogenic viruses like papillomavirus (HPV) and herpes simplex viruses (HSV) support the concept that pterygia can be considered a neoplastic condition ${ }^{(2)}$.

Because some authors postulate a potential relationship between pterygia and neoplastic lesion, some studies about the positivity of oncogenic viruses, such as HPV and HSV in the lesion were performed ${ }^{(2-6)}$.

However, HPV occurrence in pterygium lesion is still controversial and sometimes a positive correlation between pterygia and HPV infection has been reported ${ }^{(3,7-11)}$, while other present negative results ${ }^{(4,12)}$.

The present study was done with the purpose to evaluate whether HPV is involved in pterygium pathogenesis in our region.

Imunologia - Instituto de Biociências da UNESP Botucatu (SP) - Brasil.

Endereço para correspondência: Departamento de Oftalmologia da Faculdade de Medicina de Botucatu UNESP - Botucatu (SP) Zip Code 18618-000

E-mail: sartioli@fmb.unesp.br

Recebido para publicação em 31.03.2005

Versão revisada recebida em 18.11.2005

Aprovação em 12.01.2006

This research was supported by FAPESP - Fundação de Amparo à Pesquisa do Estado de São Paulo.

Nota Editorial: Depois de concluída a análise do artigo sob sigilo editorial e com a anuência da Dra. Denise de Freitas sobre a divulgação de seu nome como revisora, agradecemos sua participação neste processo.

\section{METHODS}

A randomized prospective trial was performed with 36 patients with unilateral primary pterygium assisted at the Botucatu School of Medicine São Paulo - Brazil, aged from 16 to 79 years (average 56.5), 24 (67.0\%) females and $12(33.0 \%)$ males, submitted to excision of pterygia (pterygia group) and a small sample of normal conjunctiva from the contralateral conjunctival sac (control group).

Pterygia and normal conjunctival tissue were placed in Eppendorf tubes 
with TE buffer and submitted to polymerase chain reaction (PCR) evaluation for HPV DNA detection as follows:

DNA extraction: the DNA from specimens was (obtained by the addition of proteinase $\mathrm{K}(100 \mu \mathrm{g} / \mathrm{ml})$ to the TE buffer (10 mM TRIS-HCl; pH 7.5, 1 mM EDTA,pH 7.9; 0.5\% SDS) and incubated overnight at $37^{\circ} \mathrm{C}$. The standard phenol-chloroform extraction and ethanol precipitation were used for DNA purification and the pelleted DNA was resuspended in 50-100 $\mu \mathrm{l}$ MilliQ sterile water. To determine the quality and quantity of the isolated DNA, each DNA sample was analyzed by electrophoresis on $1 \%$ agarose gels stained with ethidium bromide and viewed spectrophotometrically ${ }^{(7)}$.

HPV DNA PCR analysis: each amplification reaction was carried out in a total volume of $20 \mu$ l overlaid with one drop of mineral oil and contained $10 \mathrm{mM}$ TRIS-HCl (pH 8.3), $50 \mathrm{mM}$ $\mathrm{KCl}, 0.25$ U Taq DNA-polymerase (Perkin-Elmer), and 100-200 ng DNA. The concentration of dNTPs and $\mathrm{MgCl}_{2}$ varied with each set of primers. Each PCR was carried out in DNA thermal cycler (Perkin-Elmer CETUS DNA Thermal Cycler 480) with the first denaturation step at $92^{\circ} \mathrm{C}$ for 4 minutes and the final extension step at $72^{\circ} \mathrm{C}$ for 15 minutes. The conditions and the number of denaturation-annealing-extraction cycles were different with each set of primers.

To control the quality of the isolated DNA internally, the 150 base pair (bp) sequence of L1 gene was amplified using PC04 (5'CAACTTCATCCACGTTCACC3') primers and GH20 (5'GAAGAGCCAAGGACAGGTAC3') primers in the multiplex PCR with the MY, LC, or GP primers. DNA samples extracted from cell cultures infected with HPV were used as a positive control. Each PCR product was analyzed by electrophoresis on $2 \%$ agarose gels stained with ethidium bromide.

HPV PCR primers: the PCR mixture was complemented with $2.5 \mathrm{mM} \mathrm{MgCl}_{2}, 0.1 \mathrm{mM}$ of each dNTP, $0.5 \mu \mathrm{M}$ MY09 (CG TCCMARRGGAWACTGATC) and MY11 (GCMCAGGGW CATAAYAATGG) primers (Figure 1) and also $0.3 \mu \mathrm{M}$ PC04 and GH 20 primers. The DNA amplification was carried out during 30 cycles that included denaturation at $92^{\circ} \mathrm{C}$ for 30 seconds, annealing at $53^{\circ} \mathrm{C}$ for 30 seconds, and primer extension at $72^{\circ} \mathrm{C}$ for 30 seconds.

\section{RESULTS}

We were unable to detect any HPV DNA fragments in all specimens from both pterygia and normal conjunctival tissue (Figure 2).

\section{DISCUSSION}

Although HPV has been associated with pterygia in previous studies $^{(3,8-11)}$, our findings do not show HPV positivity in either pterygium lesion or in normal conjunctiva.

Many reasons might account for the discrepancies between the studies, including the employed method. Comparing me- thods, PCR analysis showed to be similar to immunohistochemistry and superior to the in situ hybridization for detecting HPV in squamous tumors of the conjunctiva and lacrimal sac ${ }^{(13)}$.

Using the same method as our, HPV DNA by nested PCR was also negative in all samples studied by others in pterygia, pingueculae and limbal tumors ${ }^{(4)}$.

However, HPV type 18 was detected in $24 \%$ and the herpes simplex virus (HSV) in $22 \%$ of the pterygium carriers. But in the normal conjunctiva HPV was positive in $8 \%$ and HSV was $100 \%$ negative, which might suggest that the HSV is more

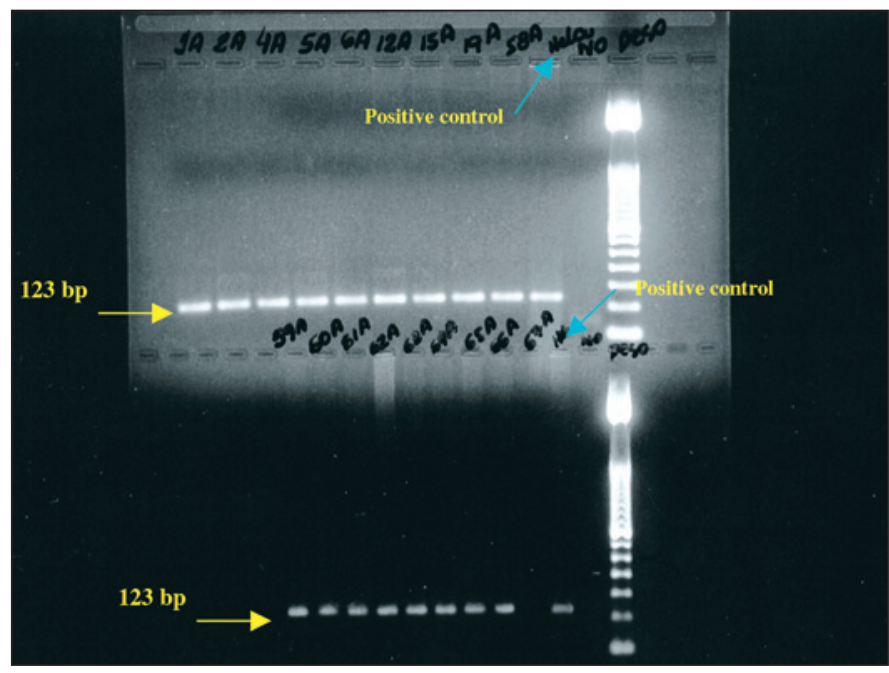

Figure 1 - PCR 120 basis pairs (bp) of L1 samples of pterygium. Positive control for HPV (HELA) amplification.

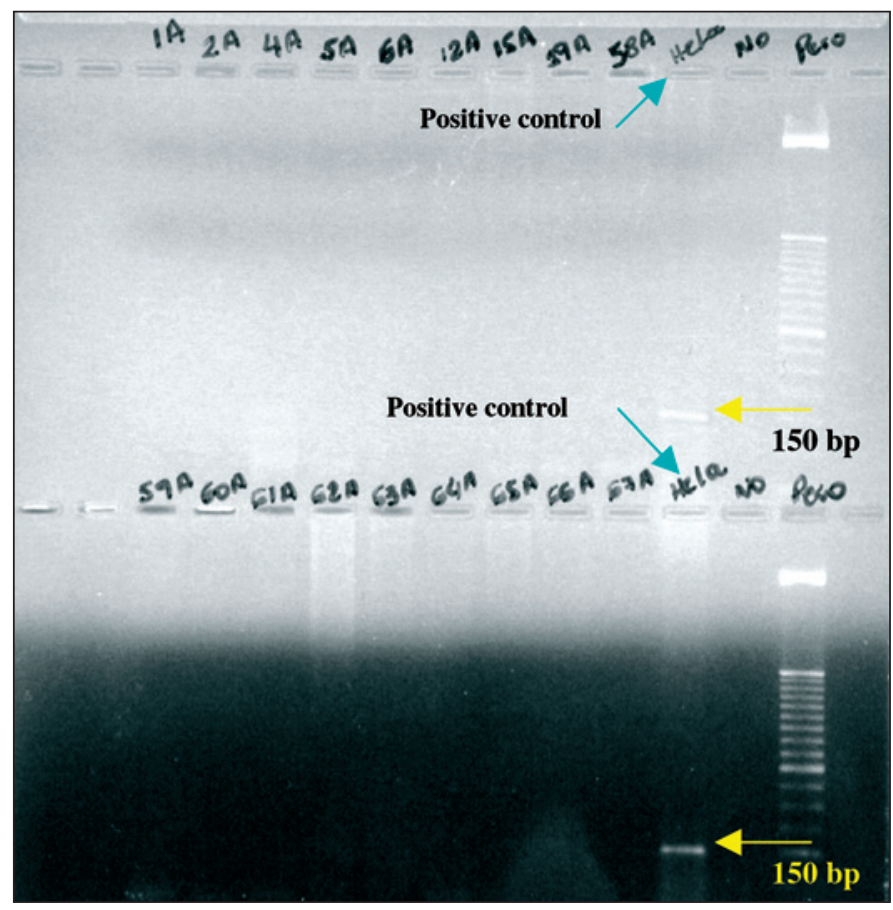

Figure 2 - PCR 150 basis pairs (bp) of L1 gene of HPV samples of pterygium. Positive control for HPV (HELA) amplification. 
specifically correlated with pterygium lesion than $\mathrm{HPV}^{(3)}$. One of the reasons to have normal conjunctiva specimen positivity is the actinic changes ${ }^{(5)}$.

According to others, HPV was identified in $50 \%$ of the pterygium samples but no HPV was detected in the control group ${ }^{(8)}$.

Another reason to account for the controversial results from the other studies and to explain the lack of positivity in our sample may be the geographic region. The incidence of HPV in pterygia was $50 \%(5 / 10)$ in the United Kingdom ${ }^{(8)}$, whereas HPV-18 was detected in 30\% (15/50) of the pterygium lesions in Greece $^{(3)}$. In CanadaHPV-16 was found in $100 \%$ of the sample of pterygia $^{(9)}$ and HPV occurred in a region of Turkey as a nonendemic infection and may be related to the development of pterygia in that region ${ }^{(10)}$. Comparing the HPV positivity in the patients with pterygium, the incidence of pterygia of Italian cases was 100\% (17/17) but 21\% (5/24) among Ecuadorian patients $^{(11)}$. And in China the HPV in pterygium samples was $100 \%$ negative, the same seen in the Botucatu region ${ }^{(12)}$.

Thus it seems that the differences in the frequency of HPV distribution in the pterygium patients could be related to geographic aspects.

Pterygium lesion development is triggered by multiple interacting factors: the relationship between ultraviolet light and HPV, the ocular surface microtrauma and the chronic inflammation due to various agents and again HPV may be one of the related agents. And the environment would have a substantial importance too.

However, because our whole sample of pterygia was negative for the HPV agent we may suppose that HPV is not necessary for the formation of pterygia and it is unlikely that HPV can act as the sole cause of the lesion.

\section{CONCLUSION}

In conclusion, according to our results, HPV infection is not necessary for pterygium formation. Further studies are required to elucidate the real role of the HPV in pterygium pathogenesis including larger samples comparing different regions.

\section{RESUMO}

Objetivo: Existem controvérsias a respeito da influência do papilomavirus (HPV) no desenvolvimento do pterígio. Assim, este estudo foi elaborado com o objetivo de verificar se o papilomavirus está presente na lesão. Métodos: Trinta e seis portadores de pterígio unilateral foram operados, preparandose o tecido removido e uma amostra de conjuntiva normal para exame de reação em cadeia da polimerase (PCR) para detecção de DNA. Resultados: Em todas as amostras do pterígio e da conjuntiva normal a pesquisa do DNA-papilomavirus por PCR resultou negativa. Conclusão: Segundo nossos resultados, o papilomavirus não é importante para o desenvolvimento do pterígio.

Descritores: Papilomavirus; Pterígio; Reação em cadeia da polimerase; Sondas DNA HPV

\section{REFERENCES}

1. Belfort Júnior R. Pterígio: In: Belfort Jr R, Kara-Jose N. Córnea clínica cirúrgica. São Paulo: Roca; 1997.

2. Detorakis ET, Drakonaki EE, Spandidos DA. Molecular genetic alterations and viral presence in ophthalmic pterygium. Int J Mol Med. 2000;6(1):35-41.

3. Detorakis ET, Sourvinos G, Spandidos DA. Detection of herpes simplex virus and human papilloma virus in ophthalmic pterygium. Cornea. 2001;20(2):164-7.

4. Dushku N, Hatcher SL, Albert DM, Reid TW. p53 expression and relation to human papillomavirus infection in pingueculae, pterygia, and limbal tumors. Arch Ophthalmol. 1999;117(12):1593-9.

5. Karcioglu ZA, Issa TM. Human papilloma virus in neoplastic and non-neoplastic conditions of the external eye. Br J Ophthalmol. 1997;81(7):595-8.

6. Scott IU, Karp CL, Nuovo GJ. Human papillomavirus 16 and 18 expression in conjunctival intraepithelial neoplasia. Ophthalmology. 2002;109(3):542-7.

7. de Roda Husman AM, Walboomers JM, van den Brule AJ, Meijer CJ, Snijders PJ. The use of general primers GP5 and GP6 elongated at their 3' ends with adjacent highly conserved sequences improves human papillomavirus detection by PCR. J Gen Virol. 1995;76(Pt 4):1057-62.

8. Gallagher MJ, Giannoudis A, Herrington CS, Hiscott P. Human papillomavirus in pterygium. Br J Ophthalmol. 2001;85(7):782-4. Comment in: $\mathrm{Br} \mathrm{J}$ Ophthalmol. 2003;87(8):1046-8.

9. Dolmetsch AM, Alcocedr CE, Scull JJ. The presence of human papillomavirus in pterygia[abstract]. Invest Ophthalmol Vis Sci. 1996;37:S43.

10. Varinli S, Varinli I, Koksal Erkisi M, Doran F. Human papillomavirus in pterygium. Cent Afr J Med. 1994;40(1):24-6.

11. Piras F, Moore PS, Ugalde J, Perra MT, Scarpa A, Sirigu P. Detection of human papillomavirus DNA in pterygia from different geographical regions. $\mathrm{Br}$ J Ophthalmol. 2003;87(7):864-6. Comment in: Br J Ophthalmol. 2003;87(7): 806-8.

12. Chen KH, Hsu WM, Cheng CC, Li YS. Lack of human papillomavirus in pterygium of Chinese patients from Taiwan. Br J Ophthalmol. 2003;87(8): 1046-8. Comment on: Br J Ophthalmol. 2001;85(7):782-4.

13. Nakamura Y, Mashima Y, Kameyama K, Mukai M, Oguchi Y. Detection of human papillomavirus infection in squamous tumours of the conjunctiva and lacrimal sac by immunohistochemistry, in situ hybridisation, and polymerase chain reaction. Br J Ophthalmol. 1997;81(4):308-13.

Nos artigios enviados para publicação, o nome dos autores e suas afiliações devem estar completos. Isso facilitará a indexação e os links com as bases de dados e o CV Lates. 